Ks. Norbert WIDOK*

\title{
POLEMIKA ANTYHERETYCKA W KATECHEZACH CYRYLA JEROZOLIMSKIEGO
}

Pośród wielu przewodników na drodze do wiary chrześcijańskiej ważne miejsce zajmuje Cyryl, biskup Jerozolimy w latach 348-387. Okazał się bowiem troskliwym pasterzem i subtelnym nauczycielem wiary ${ }^{1}$. Jego $\mathrm{Ka}$ techezy wpisują się $\mathrm{w}$ nurt nauczania katechumenalnego i mistagogicznego IV w. na Wschodzie. Stanowią zatem doskonały przykład przekazu doktryny chrześcijańskiej kandydatom do chrześcijaństwa oraz utwierdzenia jej u nowo ochrzczonych. Zawieraja pozytywny wykład prawd wiary z równoczesnym zwróceniem uwagi na postawy moralne. W Katechezach Cyryl umieścił ponadto przestrogi odnoszące się do mniej lub bardziej aktywnych grup błędnowierczych. Umiejętnie potrafił skonfrontować ortodoksyjne prawdy wiary przekazywane drogą tradycji z rozmaitymi podobnie brzmiącymi naukami, zawierającymi jednak elementy heretyckie.

Katechezy Cyryla składają się z dwóch cyklów: pierwszy z nich, poza nauką wprowadzająca, obejmuje 18 katechez wygłoszonych do katechumenów, natomiast drugi zawiera 5 tzw. katechez mistagogicznych, które zostały wygłoszone do nowo ochrzczonych. Analiza Katechez wykazała, że wypowiedzi o charakterze polemicznym względem błędów heretyckich pojawiają się jedynie w pierwszym cyklu, czyli katechezach przygotowujących katechumenów do przyjęcia chrztu, w których wykładnia poszczególnych nauk opiera się o treść symbolu przyjętego w Jerozolimie ${ }^{2}$. Zatem celem badawczym artykułu jest ukazanie spektrum atakowanych przez biskupa błędów doktrynalnych, jak i przedstawienie sposobu walki z nimi ze wskazaniem na ryzyko zafascynowania się takimi poglądami, a zwłaszcza tymi, które uchodziły jednoznacznie za herezje już powszechnie znane. Te zamierzenia zostaną zilustrowane poprzez dokonanie analizy tekstów, w których Cyryl ustosunkowuje się do poszczególnych poglądów heretyckich.

${ }^{*}$ Ks. prof. dr hab. Norbert Widok - kierownik Katedry Historii Kościoła i Patrologii na Wydziale Teologicznym Uniwersytetu Opolskiego; e-mail: nwidok@uni.opole.pl.

${ }^{1}$ Por. Quasten II 365.

${ }^{2}$ Więcej informacji na temat katechez Cyryla: W. Kania, Istotne cechy katechezy św. Cyryla Jerozolimskiego, VoxP 10 (1990) t. 18, 75-81; J. Day, Lent and the Catechetical Program in mid-fourth-century Jerusalem, StLit 35 (2005) 129-147; D.S. Kalleres, Cultivating True Sight at the Center of the World: Cyril of Jerusalem and the Lenten Catechumenate, ChH 74 (2005) 431-459. 
Nauczanie katechetyczne Cyryla było wielowątkowe, ponieważ przygotowanie katechumenów do przyjęcia chrztu musiało obejmować całość wiedzy teologicznej ${ }^{3}$. Ułatwieniem w tym zakresie dla ówczesnych pasterzy były lokalne symbole, według których przekazywano i omawiano poszczególne prawdy wiary chrześcijańskiej ${ }^{4}$. W taki sam sposób postępował także biskup Jerozolimy. W strukturze wygłoszonych katechez, a bez wątpienia wcześniej merytorycznie przygotowanych, da się zauważyć, że walka z herezjami ma kilka odsłon.

1. Założenia antyheretyckie. Jerozolimski pasterz zakłada, że rozprawianie się z naukami heretyckimi będzie dokonywało się podczas całego kursu przygotowawczego kandydatów do chrztu. Biskup bowiem w początkowych katechezach wypowiada stwierdzenia, mające charakter metodologicznych założeń, w których zawarte są antyheretyckie nawoływania, lecz nie wchodzi w szczegóły teologiczne i nie podaje imion twórców herezji.

Niezwykle wymowna jest wypowiedź zamieszczona w Katechezie wstęp$n e j$, która posiada znamiona metodologicznych założeń walki z tym, co nie jest zgodne z prawdą zawartą w przekazie Ewangelii. Jej treść jest następująca:

„Wytrwaj w tych katechezach! Choćby się nauka nasza przeciągała, niech nie ustaje twa uwaga. Otrzymasz bowiem broń przeciw wrażej mocy, przeciw heretykom, żydom, samarytanom, poganom! Przeciw wielu masz rzucać dzidy. Trzeba się więc nauczyć trafiać w pogan, walczyć z heretykami, żydami, samarytanami. Broń jest przygotowana, gotów leży miecz ducha. Musisz jednak wyciągnąć prawicę w dobrej woli, aby stoczyć walkę Pańską, zwyciężyć wraże moce, nie zostać zranionym przez żadną herezje".

Ten tekst wprowadza czytelnika w klimat ówczesnej sytuacji religijnej w kontekście prowadzonego przez biskupa kursu katechumenalnego. Cyryl bowiem w sposób dosyć zdecydowany nie tyle zachęca, co raczej nakazuje, aby jego słuchacze podjęli stanowczą walkę skierowaną wobec przeciwników religii chrześcijańskiej, do których zaliczył heretyków, żydów, samarytan oraz pogan. Te bowiem grupy składały się na społeczność miasta Jerozolimy, a także stanowiły najbliższe jego sąsiedztwo ${ }^{6}$. Bez wątpienia $\mathrm{z}$ tych społeczności

\footnotetext{
${ }^{3}$ Kilka uwag na ten temat: H. Pietras, Poczatki teologii Kościoła, Kraków 2007², 58-61.

${ }^{4}$ Oto kilka opracowań podejmujących tę kwestię: H.J. Carpenter, Creeds and Baptismal Rites in the First Four Centuries, JTS 44 (1943) 1-11; J.H. Crehan, Early Christian Baptism and the Creed, London 1950; B. Maggioni, I simboli della fede delle prime comunità cristiane, RPL 4 (1979) 9-13; H. Pietras, Geneza Symbolu Apostolskiego, w: Symbol Apostolski w nauczaniu i sztuce Kościoła, red. R. Knapiński, Lublin 1997, 63-76.

${ }^{5}$ Cyrillus Hierosolymitanus, Procatechesis 10, PG 33, 350C-351A, thum. W. Kania: Św. Cyryl Jerozolimski, Katechezy przedchrzcielne i mistagogiczne, BOK 14, Kraków 2000, 23.

${ }^{6}$ Szczegółowe informacje dotyczące tej tematyki przekazują m.in.: R.W. Hamilton, Jerusalem in the Fourth Century, „Palestine Exploration Quarterly” 84 (1952) 83-90; K.J. Conant, The Holy Sites at Jerusalem in the First to Fourth Centuries, „Proceedings of the American Philosophical
} 
mogli też pochodzić niektórzy przedstawiciele katechumenów, choć zakłada się, że większość z nich urodziła się w rodzinach chrześcijańskich. Wspomniana zachęta prowadzona jest $w$ kategoriach walki orężnej, gdyż biskup zastosował odpowiednią terminologię w takich sformułowaniach, jak: „otrzymasz bowiem broń”, ,wielu masz wrogów”, ,zaopatrz się w wiele pocisków”, „masz rzucać dzidy”, „,broń jest przygotowana”. Użyte w nich terminy przypominają wprost zachowania i postawy przyjmowane przez żołnierzy w walce, co według biskupa ma sugerować, aby taką samą walecznością odznaczali się także katechumeni.

Kolejne sformułowania podane przez pasterza w cytowanym tekście naprowadzają na walkę, którą należy stoczyć na polu przestrzeni duchowej. Są to: „gotów leży miecz ducha”, „stoczyć walkę Pańską”, a przede wszystkim w kontekście prowadzonych analiz - „nie zostać zranionym przez żadną herezję". Punktem kulminacyjnym zatem jest prowadzenie takiej walki, aby obronić zasady prawd chrześcijańskich i tym samym nie popaść w jakąś herezję. Oznacza to, że głównym zagrożeniem wspólnoty kościelnej w Jerozolimie i poza nią okazywały się grupy heretyków, których już nieco wcześniej w swej wypowiedzi Cyryl wymienił dwukrotnie, stawiając je na pierwszym miejscu, a dopiero potem umieścił żydów, samarytan i pogan.

Swego rodzaju kontynuację powyższej idei, aby nie być ugodzonym przez herezję, biskup Jerozolimy prowadzi w Katechezie 4., którą poświęcił głównym prawdom wiary. Przy okazji ich wyliczania i podawania podstawowej wiedzy teologicznej Cyryl przestrzega katechumenów przed zgubnym wpływem heretyków i stwierdza:

„Heretycy oszukują serca niewinnych swymi naukami o dobru i pięknie, imieniem Chrystusa jakby miodem smarują zatrute strzały swej bezbożnej nauki. O nich wszystkich mówi Pan tymi słowy: «Strzeżcie się, żeby kto was nie zwiódł»! Dlatego podaje się naukę wiary i wprowadza do niej"”.

Cyryl wykorzystuje tu ponownie obraz z pola walki, wskazując na strzałę jako jej nieodzowne narzędzie, która rani i zatruwa. Tym razem biskup opisał ją metaforycznie, stwierdzając, że ową trucizną jest bezbożna nauka heretyków, która w imieniu Chrystusa podawana jest przez nich jako miód. Jerozolimski pasterz zdaje sobie sprawę z tego, że kandydaci na członków wspólnoty chrześcijańskiej nie posiadają wystarczającej wiedzy biblijnej i teologicznej, aby osobiście przeciwstawić się natarciu heretyków. Stąd też oznajmia, że

Association" 102 (1958) fasc.1, 14-24; D. Rokeah, Jews, Pagans and Christians in Conflict, Jerusalem 1982; M. Dubois, What Jerusalem really means for Christians, „The Holy Land” 2 (1982) fasc. 1, 36-47; G. Stemberger, Juden und Christen im Heiligen Land. Palästina unter Konstantin und Theodosius, München 1987; P.W.L. Walker, Holy City, Holy Places? Christian Attitudes to Jerusalem and the Holy Land in the Fourth Century, Oxford 1990; M.C. Paczkowski, Rzeczywistość, symbol i tajemnica - Jerozolima w starożytnej literaturze chrześsijańskiej okresu chalcedońskiego, Wrocław 2003, 150-160.

${ }^{7}$ Cyrillus Hierosolymitanus, Catechesis 4, 2, PG 33, 455C, BOK 14, 62. 
jedynym sposobem jest przekaz tej wiedzy jako „nauki wiary” wraz z wyjaśnieniami poszczególnych jej elementów. Takie działanie zawiera od samego początku przyjęta przez biskupa strategię postępowania wobec słuchaczy.

W następnym passusie tej samej katechezy Cyryl zwraca się do katechumena w podobnym duchu, mówiąc:

„Gdy usłyszysz heretyka, jak mówi, że kto inny jest dobry, a kto inny sprawiedliwy, winieneś zaraz sobie przypomnieć prawdę, aby poznać zatrutą strzałę herezji"'.

Mówca przywołuje ten sam obraz, tj. ,zatrutą strzałę herezji”, znany słuchaczom z wcześniejszych opisów. $Z$ pewnością częste przypominanie tej metafory miało uwrażliwić każdego katechumena na zagrożenie pochodzące ze strony błędnowierców. Każdorazowa ich aktywność powinna nakłonić go do przypomnienia sobie tej prawdy, którą poznał w ramach katechumenatu. W zaleceniach zamieszczonych na zakończenie tejże katechezy Cyryl nie pomija wskazówki zawierającej ostrzeżenie swoich słuchaczy przed heretykami. Mówi do nich: „Przede wszystkim w nienawiści miej wszelkie zebrania bezbożnych heretyków!"' Trzeba przyznać, że troska biskupa o katechumenów była bardzo zdecydowana, gdyż doświadczony różnymi kwestiami pasterskimi ${ }^{10} \mathrm{Cyryl}$ doskonale rozumiał sytuację duchową tych, którzy zamierzali przyjąc chrzest.

W podobnym duchu Cyryl zakończył Katechezę 5., której tytuł brzmi: $O$ wierze $i$ symbolu, choć akcent został w niej położony głównie na wiarę. W końcowych bowiem zaleceniach mieści się jedyne w tej katechezie nawiązanie do działalności heretyków:

„Niech żaden heretyk nie wprawi was w zamieszanie w tym, czego was nauczono! Podawanie symbolu wiary jest jak wkładanie pieniędzy do banku. To właśnie uczyniliśmy, lecz Bóg zażąda od was rachunku z depozytu"11.

Cyryl w tej wypowiedzi, o charakterze konkretnej wskazówki pasterskiej, odstapił od metafory nawiązującej do walki orężnej, zapewne bliższej umysłowości osób dopiero co wpisanych na listę katechumenów, pochodzących ze świata przesiąkniętego kulturą i literaturą pogańską, w której częstymi motywami były opisy wojen i sztuki walki zbrojnej. Po wysłuchaniu kilku katechez katechumeni usłyszeli od swego biskupa zalecenie zawierające termin należący już do słownictwa teologicznego, tj. ,,symbol wiary”. Jego treść wykazuje bliskie podobieństwo z Symbolum Apostolicum ${ }^{12}$. Ponadto biskup odwołuje się do tego, co wcześniej przekazał, zakładając, że otrzymaną wiedzę

${ }^{8}$ Tamże 4, 4, PG 33, 458B-C, BOK 14, 62.

${ }^{9}$ Tamże 4, 37, PG 33, 490B, BOK 14, 75.

${ }^{10}$ Zwłaszcza jego wygnania i oskarżenia arian, por. C.M. Paczkowski, Teologia świadectwa i doświadczenia w „, Katechezach” Cyryla Jerozolimskiego, „,Quaestiones selectae” 8 (2001) 52.

${ }^{11}$ Cyrillus Hierosolymitanus, Catechesis 5, 13, PG 33, 523A, BOK 14, 85.

${ }^{12}$ Por. M. Fiedrowicz, Teologia Ojców Kościoła. Podstawy wczesnochrześcijańskiej refleksji nad wiarq, thum. W. Szymona, Kraków 2009, 222, nota 71. 
W zakresie symbolu wiary słuchacze przechowaja, tak jak przechowuje się pieniądze w banku. Następnie to wszystko Cyryl odnosi do Boga, który rozsądzi aktywność każdego z nich w tym względzie.

Przy końcu wielkopostnych nauk, tj. w Katechezie 15., a więc gdy katechumeni byli już bardziej zaawansowani w poznawaniu prawd teologicznych, Cyryl przyjmuje postawę wykazującą większe zaufanie do nich i dodaje: „Gdy dawniej heretycy byli znani otwarcie, teraz Kościół jest pełen heretyków ukrytych"13. Doświadczony w tej materii biskup w pewnym zakresie wprowadza słuchaczy w arkana życia kościelnego. Z jednej strony oznajmia o stałej aktywności heretyków w łonie Kościoła, z drugiej - przestrzega, że ich obecność przyjęła inny charakter, tzn. działają w skrytości. To stwierdzenie świadczy o trosce biskupa o losy duchowe swoich podopiecznych.

Powyższe wypowiedzi Cyryla, o charakterze założeń ewangelizacyjnych, pozwalają dostrzec $\mathrm{w}$ nim dobrego pedagoga i doświadczonego katechetę. Ich treść jest tak skonstruowana, aby uwrażliwić katechumenów, a więc mających dopiero poznać prawdy wiary chrześcijańskiej, na czyhające na nich religijne zagrożenia obecne w społeczności, w której żyli. Wypowiada się o nich w sposób ogólny, czyli traktuje wszelkie odmiany herezji jako ruch skierowany przeciw prawdziwości tez teologicznych.

2. Wykład przeciw herezjom. W Katechezach Cyryla pojawia się wiele wypowiedzi, mających charakter krótkich aluzji w odniesieniu do różnych postaw heretyckich, będących najczęściej przestrogami kierowanymi do katechumenów - wśród nich także te wyżej omówione. Natomiast o wiele dłuższą wypowiedź, przybierającą postać wykładu na temat herezji, biskup Jerozolimy zamieścił w Katechezie 6., której przedmiotem jest pierwszy artykuł symbolu wiary: „Wierzę w jednego Boga”. Zatem już u początku przekazywania słuchaczom podstaw wiary chrześcijańskiej ma miejsce ostra polemika z tymi, którzy przyczyniają się do rozbijania wspólnot chrześcijańskich poprzez głoszenie błędnych nauk i wadliwych interpretacji prawd objawionych. Tekst poświęcony herezjom zajmuje więcej niż połowę objętości tej katechezy ${ }^{14}$ i dlatego można stwierdzić, że pozytywny wykład nauki zawartej w symbolu wiary, zamieszczony w kolejnych katechezach, Cyryl poprzedził atakiem na tych, którzy odważyli się przeciwstawić tradycji apostolskiej.

Fragment poświęcony herezjom zawiera opis herezji z podaniem ich twórców, podstaw doktrynalnych i próbą polemiki Cyryla z przekazywaną przez nich błędną metodologią. Takie zamierzenie było celowym zabiegiem, co autor katechezy sam wyraźnie stwierdza:

„Musimy jednak o tym mówić, aby nikt z obecnych przez niewiedzę nie wpadł w brud heretyków. Wiem wprawdzie, że przedstawiając tę naukę,

\footnotetext{
${ }^{13}$ Cyrillus Hierosolymitanus, Catechesis 15, 9, PG 33, 882B, BOK 14, 239.

${ }^{14}$ Por. tamże 6, 12-36, PG 33, 555B - 602B, BOK 14, 95-106.
} 
plamię własne usta i uszy słuchaczy. Ale tak być musi. Bo o wiele jest lepiej w polemicznych roztrząsaniach poznać głupotę innych, niż nic o niej nie wiedzieć i dlatego w nią popaść. O wiele lepiej jest znać brud i go nienawidzić niż go nie znać i dlatego wpaść w niego"15.

Powyższy tekst ujawnia zastosowaną przez Cyryla metodykę nauczania katechetycznego. Zakłada on bowiem, że te zagadnienia, które zostały przyciemnione „brudem heretyków”, należy oczyścić poprzez „polemiczne roztrząsania". Taki sposób przekazu katechumenom zasad wiary ma - według niego - zbudować odpowiedni dla nich gmach wiedzy, aby z powodu niewiedzy nie stać się ofiarą napastliwych heretyków. To metodyczne założenie przyjęte przez biskupa Jerozolimy świadczy o jego umiejętnościach pedagogicznych $\mathrm{z}$ jednej strony ${ }^{16}, \mathrm{z}$ drugiej zaś ukazuje jego erudycję także w zakresie głoszonych wówczas różnych poglądów sprzecznych z przesłaniem Ewangelii.

Kontynuując swą wypowiedź, Cyryl dodaje, że „są jednak różne rodzaje bezbożnej nauki heretyków. Kto bowiem zboczy z prostej drogi, wpada zazwyczaj w przepaść" ${ }^{17}$. Należy zauważyć, że to stwierdzenie biskup wypowiedział do katechumenów, których na początku kursu katechetycznego uprzedził o czyhających niebezpieczeństwach na ich przyszłą religijność i pobożność. Nie wolno im zboczyć z drogi, gdyż w przeciwnym przypadku stoczą się w przepaść niewiary i bezbożności.

W swym antyheretyckim wykładzie jerozolimski katecheta przedstawił dzieje herezji, wymieniając imiona ich twórców i głoszone przez nich poglądy. Rozpoczął od czarnoksiężnika Szymona wspomnianego w Dziejach Apostolskich $(8,21)$. Ten

„jako pierwszy posunął się do bluźnierczego twierdzenia, że Ojciec, który się objawił na górze Synaj, ukazał się następnie u Żydów nie w ciele, lecz pozornie jako Jezus Chrystus, potem zaś jako Duch Święty, którego Jezus przyrzekł posłać jako Pocieszyciela"18.

Tę naukę prostowali Piotr i Paweł, dwaj przywódcy pierwotnego Kościoła. Omawiane początki działalności heretyckiej Cyryl tak ocenił:

„Szymon był pierwszym smokiem zła. Ledwie jednak jedną głowę ścięto, a okazało się, iż korzeń złego nosi wiele głów"19.

Konsekwencją tego stwierdzenia jest wypowiedź mało optymistyczna, która oznajmia, że „pustoszyli też Kościół Cerynt, Meander, Karpokrates, Ebionici

${ }^{15}$ Tamże 6, 13, PG 33, 559A-B, BOK 14, 96.

${ }^{16}$ Interesujące wnioski odnośnie do pedagogicznego aspektu katechez Cyryla Jerozolimskiego podaje M. Jędrzejewska, Droga inicjacji chrześcijańskiej w Kościele starożytnym na podstawie katechez Cyryla Jerozolimskiego, VoxP 22 (2002) z. 42-43, 408-409.

${ }^{17}$ Cyrillus Hierosolymitanus, Catechesis 6, 13, PG 33, 559B, BOK 14, 96.

${ }^{18}$ Tamże 6, 14, PG 33, 562A, BOK 14, 96.

${ }^{19}$ Tamże 6, 15, PG 33, 563B, BOK 14, 97. 
i Marcjon, owe usta bezbożności" ${ }^{20}$. Kto głosi różnych bogów, jednego dobrego, drugiego zaś sprawiedliwego, ten się sprzeciwia Synowi ${ }^{21}$. Cyryl zestawił ich obok siebie, ponieważ poglądy, które głosili były podobne, a dotyczyły Boga Ojca. W ten sposób na zasadzie błędnych opinii wygłaszanych o Nim pouczył katechumenów, kim Bóg nie jest.

Następnie w swej katechezie przechodzi jerozolimski biskup do kolejnych sylwetek niechlubnie wpisujących się w dzieje Kościoła i oznajmia:

„Po Marcjonie przyszedł inny, niesławnej pamięci, wykolejony człowiek, głosiciel bezwstydu - Bazylides. W służbie zła dołączył się jeszcze Walentyn, przyjmujący trzydziestu bogów"22.

Ta wypowiedź rozpoczyna nieco dłuższy passus, zawierający wiele szczegółów wyjętych z nauki wymienionych przedstawicieli herezji, aby ukazać katechumenom kolejne błędne interpretacje teologiczne i jednocześnie przestrzec ich przed popadnięciem w podobne błędy lub też wyeliminować ewentualnie już istniejące w ich świadomości.

Ów dłuższy opis nauki Bazylidesa i Walentyna, w którym ma miejsce głównie krytyka ich poglądów, Cyryl urozmaica wypowiedziami skierowanymi bezpośrednio do słuchaczy. Mówił do nich:

„Abyś jeszcze bardziej poczuł wstręt do heretyków, posłuchaj też, co mówią oni o Chrystusie Jezusie. [...] Opowiadam ci o tej herezji, byś ją tym więcej nienawidził. Uciekaj od tej bezbożności! Nie pozdrawiaj tych ludzi, byś nie miał udziału w dziełach ciemności! Nie pytaj się ich ciekawie i nie prowadź z nimi rozmowy!"23

Jak to ilustruje powyższy tekst, katecheta zwraca się do katechumenów w drugiej osobie, co sprawia, że w relacji pomiędzy biskupem i katechumenami pojawia się poczucie większej więzi i wzajemnego zaufania. Zatem sposób narracji Cyryla należy także do przyjętej przez niego pedagogii, dzięki której zmierza on do uzyskania zasadniczego celu, jakim jest utrwalenie w duszy słuchacza ograniczonego interesowania się obcymi poglądami religijnymi. Kieruje bowiem do nich konkretne nakazy i zakazy, jak: „uciekaj”, „,nie pozdrawiaj”, „nie pytaj”. Taki sposób wyrażania się naśladuje niektóre formy inwektywy starożytnej, którą chrześcijaństwo przejęło prawie w całości ${ }^{24}$. Nieco dalej Cyryl wyraził się podobnie:

„Nienawidź wszystkich heretyków, a zwłaszcza tego, który swe nazwisko otrzymał od szału i niedawno wystapił za cesarza Probusa. [...] Ale nie

${ }^{20}$ Tamże 6, 16, PG 33, 563B, BOK 14, 97.

${ }^{21}$ Tamże.

${ }^{22}$ Tamże 6, 17, PG 33, 566A, BOK 14, 97.

${ }^{23}$ Tamże 6, 19, PG 33, 570B - 571A, BOK 14, 98-99.

${ }^{24}$ Istotę i znaczenie inwektywy prezentuje S. Longosz, Zarys historii inwektywy wczesnochrześcijańskiej, RT 43 (1996) z. 2, 363-390. 
dlatego masz go nienawidzić, iż żył niedawno, lecz jako sprawcę złości, ściekowisko wszelkich brudów, plugastwo herezji. Aby wybić się w grzechach, pozbierał on ze wszystkich herezji to co najgorsze, i utworzył jedną z bluźnierstw i przestępstw, jak krążący dookoła lew pustosząc Kościół”25.

Również ta wypowiedź nosi znamiona mowy napastliwej, czyli wspomnianej inwektywy. Jednocześnie biskup wprowadził słuchaczy w kolejny krąg poglądów, które głosił Manes. Właśnie jemu biskup jerozolimski poświęcił najwięcej miejsca w swej katechezie ${ }^{26}$. Przytacza bowiem wiele szczegółów z jego życia, objaśnia jego błędne interpretacje Biblii, neguje zasady moralne, które wprowadzał w praktykę.

Cyryl, chcąc być wiarogodnym w oczach katechumenów, swój wywód rozpoczął słowami: „Aby nie wyglądało, że go bezpodstawnie oskarżamy, zobaczmy, kim jest ów Manes, i przedstawmy pokrótce jego życie"27. Natomiast na zakończenie swej narracji dotyczącej Manesa i jego zwolenników, tj. manichejczyków, Cyryl dodał na zasadzie konkluzji: „Tak podają książki manichejskie. Sami to czytaliśmy, gdy nie chcieliśmy wierzyć tym, którzy nam o tym mówili. Wiele zajmowaliśmy się zepsuciem manichejczyków z uwagi na wasze zbawienie"28. U biskupa Jerozolimy można więc dostrzec głęboką troskę o losy swoich słuchaczy, przede wszystkim jednak o ich zbawienie. Wiarygodność Cyryla wypływa ponadto z jego zaangażowania się w studium literatury manichejskiej, która docierała z pewnością do szerokich mas ówczesnych odbiorców. Ten intelektualny wysiłek Cyryla był konieczny, aby przekaz kerygmatu podczas katechezy umieć konfrontować z dziwnymi poglądami i praktykami manichejczyków. Nic więc dziwnego, że biskup, kończąc opis tej herezji, znowu pełen troski dopowiada: „Niech nas Bóg strzeże przed tym błędem! Bądźcie wrogami dla smoka! Gdy manichejczycy czyhają na piętę, zetrzyjcie im głowy! Nie zapominajcie tych słów!"29

$\mathrm{Na}$ podsumowanie treści całej katechezy, przed kończącym ją błogosławieństwem w imię Trójcy Przenajświętszej, Cyryl umieścił kilka zachęt i przestróg kierowanych do słuchających. Powiedział m.in.:

„Przyłącz się do owiec! Uciekaj przed wilkiem! Nie odstępuj od Kościoła! Unikaj też podejrzanych dawniej o herezję! [...] Jeśli należałeś kiedy do heretyków, nienawidź błędu, skoro go poznałeś!"’30

W tych przestrogach Cyryl podał różne możliwości, jakie mogą się pojawić $\mathrm{z}$ życiu słuchaczy. Wsłuchanie się w ich treść miało u poszczególnego

\footnotetext{
${ }^{25}$ Cyrillus Hierosolymitanus, Catechesis 6, 20, PG 33, 571A-B, BOK 14, 99.

${ }^{26}$ Por. tamże 6, 20-33, PG 33, 571A - 599A, BOK 14, 99-105.

${ }^{27}$ Tamże 6, 21, PG 33, 574A, BOK 14, 99.

${ }^{28}$ Tamże 6, 34, PG 33, 599B, BOK 14, 105.

${ }^{29}$ Tamże 6, 35, PG 33, 602A, BOK 14, 105.

${ }^{30}$ Tamże 6, 36, PG 33, 602B, BOK 14, 106.
} 
katechumena wzbudzić refleksję nad samym sobą i zweryfikować swą przynależność do danej opcji. Konsekwencją tego miała być duchowa przemiana.

Pokrótce przedstawiony wykład Cyryla na temat herezji i płynących z nich zagrożeń ukazuje wielkość tego biskupa jako pasterza i pedagoga, a przede wszystkim jako znawcy ówczesnej teologii, także jej negatywnego wydania w postaci poglądów heretyckich. Poprzez taką treść słuchaczom została dostarczona ogromna wiedza dotycząca dziejów herezji w postaci skondensowanej, a jednocześnie logicznie poukładanej. Katechumeni uświadomieni w tej materii mogli przystapić do wsłuchiwania się w pozytywny wykład jerozolimskiego symbolu wiary.

3. Antyheretycki przekaz prawd teologicznych. Wspomniany symbol wiary, który został przyjęty przez społeczność chrześcijańską w Jerozolimie, stał się dla Cyryla zasadniczym odniesieniem, według którego były wygłaszane kolejne katechezy. Treść poszczególnych tzw. artykułów wiary spisanych w jerozolimskim symbolu mniej lub bardziej inspirowała biskupa Swiętego Miasta do podjęcia polemik przeciw heretykom. Okazuje się, że najwięcej antyheretyckich wypowiedzi pojawia się w kontekście wyjaśniania różnych tematów dotyczących Osób Boskich i związanych z Nimi tzw. artykułów wiary.

Cyryl, nauczając o Bogu Ojcu, tłumaczy katechumenom, na czym polega błędne rozumowanie heretyków i wyjaśnia:

„Są bowiem tacy, którzy w swej niecnej nauce śmią dzielić jednego Boga.

Niektórzy uczyli, że kto inny jest Stwórcą i Panem duszy, a kto inny Stwórcą

i Panem ciała - bezmyślny to i bezbożny pogląd"31.

Dla biskupa nie jest istotne, kto głosił ten pogląd, ale to, na czym polega owo błędne myślenie. Ważny dla niego jest fakt, że wskazywanie na dwóch osobnych Stwórców, jednego stwarzającego dusze, a drugiego stwarzającego ciała, jest błędem.

Niezwykle sugestywnie Cyryl przemówił do katechumenów w Katechezie 7., zatytułowanej $O$ Ojcu, dostrzegając także u nich swego rodzaju sukces poznawczy. Już na początku tej katechezy nawiązuje do heretyków:

„Ścigałem też bezbożnych heretyków na ich licznych błędnych drogach. Skorośmy ich brud i zgubną dla dusz truciznę usunęli oraz wspomnieli o ich obyczajach, by nie ponieść szkody, ale by swą ku nim nienawiść jeszcze powiększyć, wróćmy teraz do siebie i znów podejmijmy zbawcze nauki o prawdziwej wierze" 32 .

Taka uwaga wypowiedziana na początku kolejnej nauki katechetycznej musiała podnieść na duchu słuchaczy przede wszystkim dlatego, że zostali dowartościowani przez biskupa. Przemawia bowiem do nich w liczbie mnogiej

\footnotetext{
${ }^{31}$ Tamże 4, 4, PG 33, 458C, BOK 14, 62.

${ }^{32}$ Tamże 7, 1, PG 33, 606A, BOK 14, 109.
} 
o wspólnych dokonaniach, czyli o dogłębnym poznaniu obyczajów heretyków i usunięciu ich ,zgubnej trucizny”. To duchowe oczyszczenie katechumenów było ponadto też osiagnięciem dydaktycznym Cyryla, stając się warunkiem przystapienia do wgłębiania się w kolejne „nauki o prawdziwej wierze” - jak wyraził się jerozolimski katecheta. Zanim pochwalił słuchaczy, sam wcześniej wspomniał o swoich osiągnięciach w ściganiu „bezbożnych heretyków”.

Cyryl w sposób podobny rozpoczął Katechezę 8., której tytuł wyraża jedną z cech Bożej istoty, a mianowicie Wszechmogacy. Początek tej katechezy brzmi następująco:

„Wiara w jednego Boga jest naszą bronią przeciw poganom i wszelkiej wrażej potędze heretyków - usuwa też ona cały błąd wielomówstwa. [...] Dodajmy również, iż jest On wszechmogący, a czynimy to tak ze względu na pogan, jak i ze względu na Żydów i wszelkich heretyków"33.

Te słowa biskupa wypowiedziane na rozpoczęcie kolejnej nauki katechetycznej stają się swoistą zapowiedzią polemiki, którą katecheta w niej podjął. Właściwie cała treść tej krótkiej katechezy jest odparciem różnych błędnych idei głoszonych przeciw wszechmocy Bożej. Uwaga mówcy w tej wypowiedzi skierowana jest także ku poganom i żydom, jednak większy nacisk został położony na walkę $\mathrm{z}$ heretykami. Biskup uświadamia katechumenom wielkość zagrożenia, jaką niosą, oraz zwraca uwagę na „potęgę” i rozmaitość „wszelkich" poglądów. W treści tej katechezy Cyryl nie wymienia z imienia żadnego przedstawiciela heterodoksji, ani nie podaje żadnej nazwy herezji, lecz skupia się na błędach interpretacyjnych, które mogą być powodem skażenia prawdziwości przekazu autentycznej nauki. Cyryl zatem nie skupia się na wiedzy religioznawczej, którą już podał we wcześniejszym wykładzie katechetycznym na temat herezji i heretyków, ale na esencji teologicznej, którą w najczystszej postaci pragnie wnieść w umysły katechumenów. Przede wszystkim jednak zależy mu na duchowości chrześcijańskiej, która oparta jest na wierze. Na nią właśnie jasno wskazuje w pierwszym zdaniu tej katechezy - ,wiara w jednego Boga jest naszą bronią".

Omówioną pokrótce katechezę Cyryl kończy podsumowaniem, zawierającym kilka odniesień do heretyków, by słuchacze ostatecznie zaakceptowali niszczycielską obecność błędnych poglądów przekazywanych w ich mieście - Jerozolimie. Zwraca się do nich:

„Jest jeden Bóg, Ojciec wszechmogący. Heretycy śmią Mu bluźnić. Odważyli się lżyć Pana Zastępów, [...]. Strzeż się wielobóstwa i wszelkiej herezji!"34

Z jednej strony biskup ustawia aktywność heretyków na płaszczyźnie grzechu, mówiąc o bluźnierstwie, z drugiej natomiast przestrzega katechumenów przed nimi, wskazując na wielkość błędnych idei, które mogą fascynować.

\footnotetext{
${ }^{33}$ Tamże 8, 1, PG 33, 626A, BOK 14, 119.

${ }^{34}$ Tamże 8, 8, PG 33, 634B, BOK 14, 122.
} 
Obok obrony wszechmocy Bożej Cyryl skupił uwagę słuchaczy także na Bogu jako Stwórcy. Tej prawdzie poświęcił Katechezę 9., w której po wyjaśnieniu zasadniczych kwestii, dodał:

„Należy pamiętać, iż Ojciec Pana naszego Jezusa Chrystusa jest tym samym, który stworzył niebo i ziemię, i zabezpieczyć się przed błędami bezbożnych heretyków, którzy śmią szydzić z najmędrszego Stwórcy wszechrzeczy”35.

Również w tej katechezie Cyryl zalicza do szyderstwa błędne interpretacje heretyków w odniesieniu do Boga. Jednocześnie stawia wymóg katechumenom, aby duchowo zabezpieczyli się przed zgubnymi ich wpływami i jeszcze raz powtarza prawdę o Stwórcy nieba i ziemi. Biskup w naukę o Stworzycielu włączył Jezusa Chrystusa, ukazując przy tym, w jakiej relacji są Oni względem siebie, zapowiadając tym samym tematykę następnej katechezy, która poucza o Synu Bożym. W kolejnych passusach tej katechezy, jerozolimski pasterz kilkakrotnie przywołał heretyków, do których za każdym razem odnosił się krytycznie $^{36}$. Wykazywał albo śmieszność ich poglądów, albo ich zagrożenie, ironizując dziwne ich idee, a przede wszystkim przestrzegając katechumenów przed naśladowaniem ich czynów.

Natomiast zdecydowanie mniej uwag polemicznych Cyryl umieścił w katechezach, w których wyjaśnia wiarę w jednorodzonego Syna (Katechezy 10-15). Umieścił w nich bowiem zaledwie pojedyncze uwagi skierowane pod adresem heretyków, zaś treść tych katechez ma charakter pozytywnego nauczania o dziełach dokonanych przez Jezusa Chrystusa. Tak oto w Katechezie 10. ma miejsce jedyne odniesienie do heretyków:

„Aby cię jednak liczne nazwy nie doprowadziły do przyjęcia wielu synów, ale zabezpieczyły przed błędami heretyków, którzy mówią, iż kim innym jest Chrystus, a kim innym Jezus, a ten znów innym, niż «drzwi» itd., słusznie brzmi wyznanie wiary: w jednego Pana Jezusa Chrystusa. Bo choćby wiele było nazw, to jednak jest jeden" ${ }^{37}$.

Ta antyheretycka aluzja podejmuje ważną kwestię teologiczną, wokół której toczyły się dyskusje w pierwszych wiekach chrześcijaństwa. Syn Boży z racji na dokonane akty zbawcze był różnie nazywany przez autorów chrześcijańskich. Różne nazwy nie oznaczały jednak różnych synów, ale stanowiły tzw. tytuły chrystologiczne posiadające poprawne przesłanie semantyczne. Słusznie zatem nauczał Cyryl, skoro z perspektywy wieków stwierdzono, że ,ten jeden tytuł w rzeczywistości rekapituluje całą tytulaturę Jezusa; a jeśli z czasem staje się nazwą, to dlatego, że w środowisku greckim został naładowany

\footnotetext{
${ }^{35}$ Tamże 9, 4, PG 33, 642A, BOK 14, 126.

${ }^{36}$ Por. tamże 9, 5-6. 8. 16, PG 33, 642B - 655A, BOK 14, 126-128. 131.

${ }^{37}$ Tamże 10, 4, PG 33, 666A, BOK 14, 135.
} 
znaczeniem zespołu pozostałych tytułów”38. Cyryl przekonuje, że właśnie wielość nazw powinna pomóc katechumenom trwać $\mathrm{w}$ wierze i w chrześcijańskiej ortodoksji. Dzięki nazwom są zabezpieczeni przed błędnymi naukami heretyków. Ostatecznie stwierdza, że nazwy odnoszące się do Zbawiciela są słuszne, ponieważ zawierają pełnię przekazu odnoszącego się do Niego, czyli że należy wierzyć w ,jednego Pana Jezusa Chrystusa”.

Biskup Jerozolimy w kolejnej katechezie kontynuuje rozważania dotyczące Jezusa Chrystusa, skupiając uwagę na Jego jednorodzoności. Ten wątek bardzo szeroko omówił w Katechezie 11., w której - podobnie jak poprzednio - zamieścił tylko jedną aluzję skierowaną do heretyków. Przestrzega katechumenów w słowach:

„Niech zamilknie wszelka herezja, która chce wprowadzić rozmaitych stwórców i budowniczych świata! Niech zamilknie język, który bluźni Chrystusowi, Synowi Bożemu! Niech zamilkną ci, którzy za Chrystusa uważają słońce! Chrystus jest stwórcą słońca, a nie słońcem, które widzisz. Niech zamilkną ci, którzy głoszą świat jako dzieło aniołów i chcą Jednorodzonego pozbawić Jego godności!"39

Ta wypowiedź jest połączeniem krytyki błędnowierców z jednoczesnym przekazaniem ortodoksyjnego nauczania o Jezusie Chrystusie. Cyryl nie wymienia z imienia przedstawicieli owych błędnowierców, ale skupia się na istocie teologicznych treści. Jerozolimski pasterz zwalcza bowiem te tendencje pośród istniejących wówczas herezji, które wymieniają różnych stwórców świata, m.in. aniołów, czy też uważają Chrystusa za słońce. Tym dziwnym naukom przeciwstawia prawdę podkreślającą godność Chrystusa Jednorodzonego, gdyż w treści całej katechezy w oparciu o argumenty biblijne ukazuje katechumenom tę prawdę wiary.

Z kolei Katecheza 12. zawiera kilka aluzji do heretyków, ponieważ jej treść odnosi się do wcielenia Jezusa Chrystusa, a ta kwestia była żywo dyskutowana w pierwszych dekadach chrześcijaństwa. Już na początku katechezy biskup stanowczo oznajmia:

„Przyjmujemy bowiem, iż Słowo Boże prawdziwie stało się człowiekiem, nie - jak chcą heretycy - z woli męża i żony, lecz według Ewangelii - z Dziewicy i Ducha Świętego, nie pozornie, lecz prawdziwie. Poczekaj jeno trochę na naukę o tym, a otrzymasz dowody, że Słowo prawdziwie przyjęło naturę ludzką z Dziewicy"40.

Omawiana katecheza została zatytułowana: Który przyjąt ciało i stat się człowiekiem. Każdy ówczesny nauczyciel wiary przedstawiając tę prawdę o Jezusie

${ }^{38}$ B. Sesboüé - J. Wolinski, Historia dogmatów, t. 1: Bóg zbawienia, thum. P. Rak, Kraków 1999, 100.

${ }^{39}$ Cyrillus Hierosolymitanus, Catechesis 11, 21, PG 33, 718B-C, BOK 14, 157.

${ }^{40}$ Tamże 12, 3, PG 33, 727C - 730A, BOK 14, 164. 
Chrystusie musiał odznaczać się wiedzą i umiejętnością właściwego przekazu. Prawda ta dotyczy bowiem połączenia w Nim dwóch natur: boskiej i ludzkiej, a wokół tego zagadnienia pojawiło się sporo interpretacji ${ }^{41}$. Powyższy fragment zawiera oświadczenie biskupa Cyryla, że jest świadomy właściwej wykładni tej teologicznej kwestii. Uprzedza o tym katechumena, kiedy mówi: „Poczekaj jeno trochę na naukę o tym, a otrzymasz dowody", co oznacza, że cała treść tej katechezy będzie solidnym pouczeniem na temat wcielenia Jezusa Chrystusa. Jej treść ukazuje, że całość dowodów jerozolimski pasterz opiera o treści biblijne, wykazując tym samym błędne założenia heretyków.

W powyższej wypowiedzi na uwagę zasługuje powtarzające się trzykrotnie słowo ,prawdziwie”, oznaczające, że Słowo Boże „prawdziwie” przyjęło ludzką naturę, a nie pozornie. Jest to bowiem zasadnicza teza, wokół której toczyły się dyskusje od pierwszych pokoleń chrześcijańskich. Na początku II w. bardzo intensywnie tę prawdę podkreślał Ignacy Antiocheński, kiedy wypowiadał się o Jezusie Chrystusie ${ }^{42}$. Z jednakowo wielką mocą tak samo nauczał w IV w. Cyryl Jerozolimski, z czego wynika, że ów teologiczny spór tak szybko nie wygasł w polemikach wczesnochrześcijańskich. Dlatego w swej katechezie, zanim biskup wyłoży naukę o wcieleniu, oznajmia katechumenom, jakie błędy w tej materii jeszcze istnieją:

„Wieloraki jest błąd heretyków. Jedni całkowicie odrzucili Jego narodzenie z Dziewicy. Inni wprawdzie przyjęli Jego narodzenie, ale nie z Dziewicy, lecz z zamężnej kobiety. Jeszcze inni twierdza, że nie Chrystus Bóg stał się człowiekiem, lecz człowiek stał się Bogiem. Odważyli się nawet powiedzieć, że człowiekiem stał się nie Logos (Słowo) istniejący uprzednio, lecz że człowiek jakiś wzniósł się wysoko i otrzymał wieniec" ${ }^{\text {"43 }}$.

Słowa tej wypowiedzi świadczą o wiedzy Cyryla na temat ówczesnych poglądów heretyckich, a także stanowią istotne źródło informujące o różnorodności istniejących jeszcze wówczas błędów chrystologicznych. Wyliczenie ich na początku katechezy miało uświadomić słuchaczom, jak ważną naukę usłyszą od swego pasterza, odnoszącą się do właściwego postrzegania Zbawiciela. Dlatego Cyryl w dalszych passusach katechezy nie omawia szczegółowo

\footnotetext{
${ }^{41} \mathrm{~W}$ sposób całościowy omawia je G. Jaśkiewicz, Doketyzm jako wyraz relatywizmu w teologii, Ząbki 2011.

${ }^{42}$ Por. Ignatius Antiochenus, Epistula ad Trallianos 9, 1-2, ed. P.Th. Camelot, w: Ignace d'Antioche, Polycarpe de Smyrne, Lettres. Martyre de Polycarpe, SCh 10, Paris 1969, 118, thum. A. Świderkówna: Ignacy do Kościoła w Tralleis, w: Pierwsi świadkowie. Pisma Ojców Apostolskich, BOK 10, Kraków 1998, 126: „który naprawdę się narodził, który jadł i pił, naprawdę był prześladowany za Poncjusza Piłata, naprawdę został ukrzyżowany i umarł [...]. On też naprawdę powstał z martwych"; Epistula ad Smyrnaeos 1, 1-2, ed. P.Th. Camelot, SCh 10, 154-156, tłum. A. Świderkówna: Ignacy do Kościoła w Smyrnie, BOK 10, 136: „który będąc naprawdę według ciała z rodu Dawida, jest Synem Bożym według woli i potęgi Ojca, naprawdę urodził się z Dziewicy, [...], a za Poncjusza Piłata i tetrarchy Heroda naprawdę został przybity za nas w ciele".

${ }^{43}$ Cyrillus Hierosolymitanus, Catechesis 12, 3, PG 33, 730A, BOK 14, 164.
} 
poszczególnych błędów, ale jedynie przestrzega katechumenów przed heretykami krótkimi sformułowaniami, takimi jak: „Niech zamilkną heretycy, którzy oskarżają ciało i samego Stwórcę!”44, „Nie cierpmy heretyków uczących, że przyjście Chrystusa było tylko pozorne!”45, „Nieskalane było cielesne narodzenie Syna z Dziewicy. Gdy heretycy sprzeciwiają się tej prawdzie, zwycięży ich Duch Święty"46. Kończąc katechezę, biskup ponownie zgromił swych przeciwników: „Niech więc zamilkną heretycy, przeczący Jego ludzkiej naturze" ${ }^{\prime 4}$. Wszystkie te aluzje antyheretyckie zawierają w swej treści prawdę o wcieleniu Jezusa Chrystusa z jednoczesnym odrzuceniem wszelkich błędnych opinii. Zatem nauczanie Cyryla o wcielonym Zbawicielu stanowiło podstawowy przekaz ówczesnej wiedzy teologicznej ze zwróceniem uwagi na tych, którzy odważyli się nauczać inaczej ${ }^{48}$.

Kolejne odniesienie do heretyków ma miejsce w Katechezie 14., która poucza o zmartwychwstaniu, wniebowstapieniu i siedzeniu Chrystusa na prawicy. Biskup ostrzega dosyć stanowczo każdego ze swych słuchaczy: „Niech cię żaden heretyk nie skłoni do zniesławienia zmartwychwstania!”, po czym dodaje: „Bo dziś manichejczycy ucza, że zmartwychwstanie Zbawiciela było tylko przywidzeniem, a nie prawdą"49. Obok ostrzeżenia przed heretykami Cyryl wskazuje, kogo należy się obawiać. Warto także zauważyć, że w 2. poł. IV w. nauka manichejczyków ciaggle była jeszcze głoszona, skoro do niej właśnie biskup czyni aluzję. W innym miejscu tej katechezy ma miejsce natomiast odrzucenie błędnego poglądu, co ujął jerozolimski pasterz w ten sposób:

„Nie zgadzamy się jednak z tymi, którzy błędnie twierdzą, że Syn dopiero po ukrzyżowaniu, zmartwychwstaniu i wniebowstapieniu siedzi po prawicy Ojca. Bo nie z biegiem czasu tron otrzymał, lecz odkąd jest - a został zrodzony od wieków - siedzi z Ojcem" ${ }^{50}$.

Również w tej wypowiedzi obok przestrogi biskup zawarł konkretny przekaz ważnej prawdy teologicznej, konfrontując ze sobą opinię błędną i prawdziwą. Taki sposób przekazu miał pomóc słuchaczom w przyswojeniu ortodoksyjnej nauki o Jezusie Chrystusie jako Osoby w Trójcy Świętej.

Katecheza 15. jest ostatnim pouczeniem odnoszącym się do Jezusa Chrystusa, który przyjdzie sądzić żywych i umarłych. W jej treści pojawia się bardzo interesujące stwierdzenie w odniesieniu do heretyków:

${ }^{44}$ Tamże 12, 26, PG 33, 758B, BOK 14, 175.

${ }^{45}$ Tamże 12, 31, PG 33, 763A, BOK 14, 177.

${ }^{46}$ Tamże 12, 32, PG 33, 766B, BOK 14, 178.

${ }^{47}$ Tamże 12, 33, PG 33, 766C, BOK 14, 179.

${ }^{48} \mathrm{~W}$ tym czasie pojawiały się już syntezy i wypowiedzi przeciwko heretykom, zwłaszcza ogłaszane przez lokalne synody, których treść Cyryl Jerozolimski bez wątpienia mógł znać. Na ich temat zob. Historia teologii, t. 1: Epoka patrystyczna, red. A. di Berardino - B. Studer, tłum. M. Gołębiewski i inni, Kraków 2002, 520-524.

${ }^{49}$ Cyrillus Hierosolymitanus, Catechesis 14, 21, PG 33, 851A, BOK 14, 223.

${ }^{50}$ Tamże 14, 27, PG 33, 862A, BOK 14, 227. 
„Gdy dawniej heretycy byli znani otwarcie, teraz Kościół jest pełen heretyków ukrytych"s1.

Jest to jednocześnie opinia Cyryla na temat jakości wspólnoty kościelnej, w której ciaggle obecni byli heretycy, jednak prezentujący swe poglądy w sposób bardziej ukryty. Tego typu eklezjalny status ukształtowany był działalnością antyheretycką ówczesnych cesarzy, którzy wydawanymi ustawami przeciw błędnowiercom wpływali na wizerunek ówczesnego Kościoła ${ }^{52}$. Również w tej katechezie Cyryl zachęca do czujności, mówiąc: „Gdybyś kiedyś słyszał, iż Królestwo Chrystusowe skończy się, gardź taką herezją!"53 To krótkie stwierdzenie zawiera przestrogę o błędnej opinii, której należy się wystrzegać, i jest jednocześnie informacją o istnieniu wówczas heretyckiego zapatrywania o takiej treści. W podsumowaniu wyłożonej nauki w omawianej katechezie Cyryl pośród wielu przypomnień nie omieszkał wspomnieć także o przeciwnikach nauki Kościoła, mówiąc: „Unikaj wszelkiej herezji!" ${ }^{54}$. Słowa o podobnej treści pojawiały się już w poprzednich katechezach.

Dwie kolejne katechezy zostały poświęcone Duchowi Świętemu. Po kilku wstępnych refleksjach w Katechezie 16. wprowadzających słuchaczy do przyjęcia nowej wiedzy teologicznej Cyryl najpierw bardzo stanowczo rozprawia się z poglądami heretyckimi. Mając na uwadze głoszoną tego dnia prawdę, zwraca się do katechumenów:

„Nadzieja nasza jest w Ojcu i Synu i Duchu Świętym. Nie uczmy o trzech Bogach. Niech zamilkną marcjoniści! Głosimy z Duchem Świętym przez jednego Syna jednego Boga. Niepodzielna jest wiara, nierozłączna pobożność. Nie dzielimy Trójcy Świętej, jak to niektórzy czynią, ani jej nie mieszamy jak Sabeliusz" $" 55$.

Powyższa wypowiedź rozpoczyna serię antyheretyckich ataków Cyryla zawartych w kolejnych passusach tej mowy. W przytoczonych tu słowach biskup przekazał katechumenom trynitarną prawdę, której należy przestrzegać, z jednoczesnym wskazaniem na twórców błędnych poglądów. Wymienił bowiem marcjonistów i Sabeliusza oraz ich błędne teorie. W katechezach wcześniejszych, dotyczących Boga Ojca i Jezusa Chrystusa, mówca generalnie unikał wskazywania z imienia heretyków. Skupił się raczej na przekazie pozytywnego nauczania o tych Boskich Osobach ${ }^{56}$. Natomiast w tej katechezie przyjął

${ }^{51}$ Tamże 15, 9, PG 33, 882B, BOK 14, 239.

${ }^{52}$ Szczegółowo tę problematykę omawia M. Stachura, Heretycy, schizmatycy i manichejczycy wobec cesarstwa rzymskiego (lata 324-428, wschodnia część Imperium), Kraków 2000, 55-119.

${ }^{53}$ Cyrillus Hierosolymitanus, Catechesis 15, 27, PG 33, 910A, BOK 14, 249.

${ }^{54}$ Tamże 15, 33, PG 33, 915A, BOK 14, 252.

${ }^{55}$ Tamże 16, 4, PG 33, 922A, BOK 14, 258.

${ }^{56} \mathrm{Na}$ temat trynitarnych aspektów w katechezach Cyryla wypowiedział się A.A. Stephenson, Saint Cyril Trinitarian Theology, StPatr 11 (1972) 234-241. 
odmienną taktykę, do której sam się przyznaje, uprzedzając tym samym różne oczekiwania słuchaczy:

„Mówiąc o Duchu Świętym, nie zamierzamy dawać dokładnie wyjaśnienia Jego natury - bo jest to niemożliwe; chcemy tylko wymienić dotyczące Go różne błędy, abyśmy kiedyś nie popadli w nie przez niewiedzę. Chcemy odciąć błędne drogi, by kroczyć jedyną drogą królewską. Jeśli przytoczymy jedną czy drugą wypowiedź heretycką, uczynimy to dla swego zabezpieczenia, sama zaś wypowiedź niech spadnie na głowę heretycką" ${ }^{\prime \prime}$.

Punkt wyjścia do rozważań o Duchu Świętym jest bardzo jasny: skupić się jedynie na błędnych opiniach, które należy odrzucić, a wówczas ukaże się właściwa droga do zrozumienia istoty tej Boskiej Osoby. Cyryl bowiem zdaje sobie sprawę, że „wyjaśnienie Jego natury jest niemożliwe”, wchodząc przez takie założenie w przestrzeń bezpiecznej wykładni teologicznej. Innymi słowy, poprzez wskazanie fałszywych, czyli już zweryfikowanych, orzekań o Duchu Świętym można - według jerozolimskiego katechety - dojść do prawdziwej wykładni na Jego temat. Dlatego w dalszych etapach swej katechezy biskup skoncentrował się jedynie na potępianiu różnych heretyków, wymieniając ich imiona ${ }^{58}$.

W drugiej katechezie o Duchu Świętym, tj. w Katechezie 17., biskup skupił się głównie na interpretowaniu tekstów biblijnych dotyczących Trzeciej Osoby Boskiej. Jedynie przy końcu swej mowy katechetycznej krótko ostrzegł o istniejących wówczas „rozłamach, bo przeróżny jest błąd heretyków”.59. Treść zatem tej katechezy stanowi w miarę szeroką naukę o Duchu Swiętym, konieczną w przygotowaniach katechumenów do przyjęcia chrztu ${ }^{60}$.

Ostatnia katecheza przedchrzcielna zawiera kilka wątków doktrynalnych zaczerpniętych z symbolu jerozolimskiego, a więc aktu wiary „w jeden, święty, powszechny Kościół, ciała zmartwychwstanie i życie wieczne”-jak też została zatytułowana Katecheza 18. Biskup w swym katechetycznym przekazie

${ }^{57}$ Cyrillus Hierosolymitanus, Catechesis 16, 5, PG 33, 923B, BOK 14, 259.

${ }^{58}$ Por. tamże 16, 6, PG 33, 925A, BOK 14, 259: „Jedni - jako pierwszy Szymon, zwany w Dziejach Apostolskich czarnoksiężnikiem - odważyli się stwierdzić, iż sami są Duchem Świętym. [...]. Inni znów, tak zwani gnostycy, również bezbożni, inne rzeczy powiedzieli przeciw Duchowi Świętemu, niegodziwi walentynianie jeszcze inne. Bezbożny Manes bezczelnie się głosił za Pocieszyciela”; 16, 7, PG 33, 925B - 928A, BOK 14, 259-260: „Nienawidzić też należy marcjonistów, co z Nowego Testamentu wyrzucili słowa Starego Przymierza. Bezbożny Marcjon, który pierwszy głosił trzech Bogów, [...]. Nienawidzić też trzeba wspomnianych gnostyków, w rzeczywistości zaś są pełni niewiedzy, skoro głoszą tak zuchwałą naukę o Duchu Świętym”; 16, 8, PG 33, 928A, BOK 14, 260: „Nienawidzić też należy katafrygów i założyciela tego zła Montanusa, z jego dwiema rzekomymi prorokiniami, Maksymillą i Pryscyllą”; 16, 9, PG 33, 929A-B, BOK 14, 260: „Po nim stanął do walki - jak już powiedzieliśmy - bezbożny Manes, który pozbierał razem błędy herezji”; 16, 10, PG 33, 932A, BOK 14, 261: „Jeśli więc Szymon, który chciał nabyć «moc» za pieniądze, został potępiony, jak wielka musiała być bezbożność Manesa, który głosił, iż jest Duchem Świętym!"

${ }^{59}$ Cyrillus Hierosolymitanus, Catechesis 17, 33, PG 33, 1006C, BOK 14, 292.

${ }^{60}$ Nauczanie o Duchu Świętym w ujęciu Cyryla Jerozolimskiego opracował C. Granado, Pneumatologia de San Cirilo de Jerusalém, EE 58 (1983) 421-490. 
omawia wymienione prawdy wiary, nie dyskutując za wiele z heretykami. Jedynie w krótkich stwierdzeniach odnosi się do nich pod koniec katechezy, ostrzegając: „Nie mówimy jak heretycy, iż ciało jest obcą szatą! Ale baczmy na nie, bo jest ono naszą własnością"61. Biskup Jerozolimy bardzo twórczo potraktował to zagadnienie, zwłaszcza że był dobrze obeznany z ówczesnymi zarzutami ${ }^{6}$. W kontekście zmartwychwstania ciała biskup podkreśla wartość sfery cielesnej, która także została zbawiona. Przede wszystkim jednak dozna szczególnej przemiany w akcie zmartwychwstania. Dlatego poniżanie cielesności i kierowanie się fałszywymi naukami jest postawą sprzeczną z wiarą chrześcijańską.

Natomiast odnosząc się do wspólnoty kościelnej, Cyryl wyjaśnia, na czym polega różnica pomiędzy zgromadzeniem heretyków a katolików. Jego pouczenie brzmi następująco:

„Mógłby więc ktoś powiedzieć, że i zgromadzenie bezbożnych heretyków, marcjonistów, manichejczyków i innych są też we właściwym znaczeniu kościołem. Dlatego przestrzega cię wyznanie wiary, każąc ci wierzyć «w jeden, święty, powszechny Kościół» i unikać zgromadzenia heretyków, a trzymać się zawsze wiernie świętego, powszechnego Kościoła, w którym się odrodziłeś" ${ }^{63}$.

Weryfikacja prawdziwości tej wspólnoty kościelnej, którą reprezentował biskup Cyryl, polega na dostrzeżeniu tzw. znamion Kościoła, wymienionych w symbolu jerozolimskim. Wszelkie inne zgromadzenia, które nie cieszą się tymi cechami, są wspólnotami heretyckimi. Dlatego w celu ukazania tej różnicy pasterz Jerozolimy aż dwukrotnie powtarza zasadę, aby wierzyć w Kościół jeden, święty i powszechny. Należy ponadto zauważyć, że nie podał czwartego znamienia Kościoła, którym jest jego apostolskość. Cyryl dał katechumenom do zrozumienia, że wspólnoty marcjonistów i manichejczyków to bezbożni heretycy, których nie można zaliczyć do wspólnoty Kościoła.

$* * *$

Katechezy przedchrzcielne Cyryla Jerozolimskiego obfitują w bardzo różnorodną treść teologiczną, na tyle wieloaspektową, by dzięki niej każdy katechumen był dobrze przygotowany do przyjęcia chrztu. Obok teologicznego wyjaśnienia treści symbolu wiary biskup uzupełniał ich pozytywny wykład, na zasadzie przeciwstawienia i weryfikacji, informacjami dotyczącymi poglądów heretyckich. Okazuje się, co dowodzi wyżej dokonana analiza odpowiednich tekstów, że biskup Jerozolimy był doskonale zorientowany co do istniejących i działających za jego czasów różnych nurtów błędnej interpretacji Pisma

\footnotetext{
${ }^{61}$ Cyrillus Hierosolymitanus, Catechesis 18, 20, PG 33, 1042A, BOK 14, 308.

${ }^{62}$ Por. J.N.D. Kelly, Poczatki doktryny chrześcijańskiej, thum. J. Mrukówna, Warszawa 1988, 352.

${ }^{63}$ Cyrillus Hierosolymitanus, Catechesis 18, 26, PG 33, 1047A-B, BOK 14, 310-311.
} 
Świętego. Tym samym ujawnił też swoją wiedzę teologiczną którą prezentował podczas regularnie odbywanych spotkań katechetycznych z katechumenami w okresie Wielkiego Postu. W sposób umiejętny zestawiał wykładane treści teologiczne z błędnymi podejściami heretyków, aby słuchacze mogli dostrzec różnicę w interpretacji danej kwestii i odrzucali tę błędną.

Katechezy Cyryla ujawniły ponadto jego zdolności pedagogiczne. W zależności bowiem od wagi i znaczenia danej kwestii teologicznej swoje odniesienia i aluzje do herezji umieszczał w odpowiednim miejscu danej katechezy. I tak po uwagach wprowadzających na temat istoty chrztu w pierwszych katechezach, interpretację symbolu chrzcielnego poprzedził obszernym wykładem zawierającym opis znanych ówcześnie herezji, ich założycieli oraz głoszonych przez nich poglądów. Natomiast poszczególne błędne podejścia zamieszczał przy omawianiu danej prawdy teologicznej, konfrontując ze sobą przekazywane treści. Dzięki takiej metodzie podawczej Cyryl okazał się także wytrawnym polemista, potrafiącym z jednej strony wykazać fałszywe założenia błędnych poglądów, $\mathrm{z}$ drugiej zaś ochronić niedoświadczone w sprawach teologicznych umysły katechumenów przed popadnięciem w fałszywe teorie. Niejednokrotnie korzystał z inwektywy jako środka stylistycznego ówczesnej sztuki retorycznej.

\section{THE ANTIHERETICAL POLEMIC \\ IN THE CATECHESIS OF CYRIL OF JERUSALEM}

\section{(Summary)}

The research goal the article was to present the ways of polemical fight of Cyril of Jerusalem in pre-baptismal catecheses given by him during the period of Lent. Catechumens, listening to catechetical speeches of their bishop, often learned about the existence of various theological misinterpretation. The Jerusalem shepherd noted at the beginning of his cycle of catecheses that he would pay attention to the heretical views.

The bishop included an extensive description of the existing at that time false faith groups in one of the initial catechesis to sensitize the listeners to the spiritual evil introduced into their minds by heretics. The particular theological truths the bishop explained on the basis of the Articles of Faith contained in the so-called symbol of Jerusalem. In every consecutive teaching Cyril referred to these erroneous views that concerned the currently explained theological issue. Through their juxtaposition the listeners could better understand and at the same time distinguish the true interpretation of the faith from its misinterpretation. The bishop of Jerusalem turned out to be not only an outstanding theologian, but also a good polemicist, and an excellent teacher. 
Key words: Cyril of Jerusalem, antiheretical polemic, heretical views, catechumens, pre-baptismal catechesis.

Słowa kluczowe: Cyryl Jerozolimski, polemika antyheretycka, heretyckie poglądy, katechumeni, katecheza przedchrzcielna.

\section{BIBLIOGRAFIA}

\section{Źródła}

Cyrillus Hierosolymitanus, Catecheses, PG 33, 331-1057, tłum. W. Kania: Św. Cyryl Jerozolimski, Katechezy przedchrzcielne i mistagogiczne, BOK 14, Kraków 2000.

Ignatius Antiochenus, Epistula ad Smyrnaeos, ed. P.Th. Camelot, w: Ignace d'Antioche, Polycarpe de Smyrne, Lettres. Martyre de Polycarpe, SCh 10, Paris 1969, 154-168, tłum. A. Świderkówna: Ignacy do Kościoła w Smyrnie, w: Pierwsi świadkowie. Pisma Ojców Apostolskich, BOK 10, Kraków 1998, 136-139.

Ignatius Antiochenus, Epistula ad Trallianos, ed. P.Th. Camelot, w: Ignace d'Antioche, Polycarpe de Smyrne, Lettres. Martyre de Polycarpe, SCh 10, Paris 1969, 110-122, thum. A. Świderkówna: Ignacy do Kościoła w Tralleis, w: Pierwsi świadkowie. Pisma Ojców Apostolskich, BOK 10, Kraków 1998, 124-127.

\section{Opracowania}

CARPenter H.J., Creeds and Baptismal Rites in the First Four Centuries, JTS 44 (1943) $1-11$.

Conant K.J., The Holy Sites at Jerusalem in the First to Fourth Centuries, „Proceedings of the American Philosophical Association" 102 (1958) fasc. 1, 14-24.

Crehan J.H., Early Christian Baptism and the Creed, London 1950.

DAY J., Lent and the Catechetical Program in mid-fourth-century Jerusalem, StLit 35 (2005) 129-147.

Dubois M., What Jerusalem really means for Christians, „The Holy Land” 2 (1982) fasc. $1,36-47$.

Fiedrowicz M., Teologia Ojców Kościoła. Podstawy wczesnochrześcijańskiej refleksji nad wiara, tłum. W. Szymona, Kraków 2009.

Granado C., Pneumatologia de San Cirilo de Jerusalém, EE 58 (1983) 421-490.

Hamilton R.W., Jerusalem in the Fourth Century, „Palestine Exploration Quarterly” 84 (1952) 83-90.

Historia teologii, t. 1: Epoka patrystyczna, red. A. di Berardino - B. Studer, thum. M. Gołębiewski i inni, Kraków 2002.

JAŚKIEWICZ G., Doketyzm jako wyraz relatywizmu w teologii, Ząbki 2011.

JĘDRZEJEwska M., Droga inicjacji chrześcijańskiej w Kościele starożytnym na podstawie katechez Cyryla Jerozolimskiego, VoxP 22 (2002) z. 42-43, 403-409.

Kalleres D.S., Cultivating True Sight at the Center of the World: Cyril of Jerusalem and the Lenten Catechumenate, ChH 74 (2005) 431-459.

Kania W., Istotne cechy katechezy św. Cyryla Jerozolimskiego, VoxP 10 (1990) t. 18, $75-81$.

Kelly J.N.D., Poczatki doktryny chrześcijańskiej, thum. J. Mrukówna, Warszawa 1988.

Longosz S., Zarys historii inwektywy wczesnochrześcijańskiej, RT 43 (1996) z. 2, 363-390.

MagGioni B., I simboli della fede delle prime comunità cristiane, RPL 4 (1979) 9-13. 
Paczkowski C.M., Teologia świadectwa i doświadczenia w „,Katechezach” Cyryla Jerozolimskiego, „Quaestiones selectae” 8 (2001) 52-73.

Paczkowski M.C., Rzeczywistość, symbol i tajemnica - Jerozolima w starożytnej literaturze chrześcijańskiej okresu chalcedońskiego, Wrocław 2003.

Pietras H., Geneza Symbolu Apostolskiego, w: Symbol Apostolski w nauczaniu i sztuce Kościoła, red. R. Knapiński, Lublin 1997, 63-76.

Pietras H., Poczqtki teologii Kościoła, Kraków $2007^{2}$.

Quasten J., Patrologia, vol. 2: I Padri greci (secoli IV-V), Casale 1983.

Rokeah D., Jews, Pagans and Christians in Conflict, Jerusalem 1982.

SesboüÉ B. - Wolinski J., Historia dogmatów, t. 1: Bóg zbawienia, tłum. P. Rak, Kraków 1999.

Stachura M., Heretycy, schizmatycy i manichejczycy wobec cesarstwa rzymskiego (lata 324-428, wschodnia czesść Imperium), Kraków 2000.

Stemberger G., Juden und Christen im Heiligen Land. Palästina unter Konstantin und Theodosius, München 1987.

Stephenson A.A., Saint Cyril Trinitarian Theology, StPatr 11 (1972) 234-241.

Walker P.W.L., Holy City, Holy Places? Christian Attitudes to Jerusalem and the Holy Land in the Fourth Century, Oxford 1990. 